\title{
Effect of Capital Flight on Foreign Direct Investment: Evidence from Multinational Corporations in Developing African Countries
}

\author{
Joseph, Fineboy Ikechi $^{1}$--- (D) Omodero, Cordelia Onyinyechi ${ }^{*}$--- J. U. Ihendinihu ${ }^{3}$ \\ ${ }^{1,2}$ Clifford University, Owerrinta, Abia State, Nigeria. \\ Email:fayooxyz2009@yahoo.com \\ 'Email:cordeliaomodero@yahoo.com \\ ${ }^{s}$ Michael Okpara University of Agriculture, Umudike, Abia State, Nigeria. \\ ${ }^{s}$ Email:ihendinihu.john@gmail.com
}

\begin{abstract}
This study investigates the effect of capital flight on foreign direct investment in developing nations of Africa. Secondary data employed for this study are obtained for Nigeria, Gabon, Botswana, Cameroon and South Africa from 2005-2014. The study adopts ordinary least square regression analysis to test the hypothesis of the study. The result from the regression analysis shows that capital flight has significant impact on foreign direct investment which represents $t$-statistic of 2.531 with $F$ - statistic $=21.70 ; R 2=0.837$, and $R-2=0.701$ with the p-value $0.016<0.05 \%$. It very well may be concluded from the outcome acquired that the consistent parameter over the long haul is certain. This infers if all the informative factors are held steady, outside direct speculation (FDI) will expand subsequently realizing expanded business age, increment Gross Domestic Product (GDP) of these countries, decline financing costs, sway decidedly on trade rates just as assistance in country working in less created countries. This study concluded that capital flight has a significant impact on foreign direct investment in developing nations of Africa. It therefore, recommends that foreign investors and MNCs should be meant to stop illicit outflows via capital flight through more stringent international tax laws aimed at entrenching transparency on how MNCs file in their tax returns.
\end{abstract}

Keywords: Illicit financial flows, Multinational firms, Tax evasion, Tax avoidance.

JEL Classification: E26; F23; H26; H39.

Licensed: This work is licensed under a Creative Commons Attribution 4.o License.

Funding: This study received no specific financial support.

Competing Interests: The authors affirm that they have no conflicting interests.

Acknowledgement: The authors thank the anonymous reviewers and editors of Themes in Applied Sciences Research for their contributions that improved the quality of this paper. The authors are also obliged to Dr. (Mrs.) Cordelia O. Omodero for the proofreading of the work.

\section{Introduction}

As indicated by Service Center for Development and Cooperation (2010) unlawful capital flight is much of the time executed through expense sanctuaries by MNCs. It has been observed that the term 'Unlawful Financial Flows (IFF) started to be intently connected with capital trip to clarify various illicit cross fringe exercises and it is as of late being utilized to depict development of capital or exercises or all the more plainly cash that is wrongfully earned, moved or utilized crosswise over outskirts. This examination has received the 
two terms 'unlawful money related streams and capital flight' in view of the contentions/discusses encompassing the meager line between the two terms and the contention stays uncertain and nearly equivalent to we will see beneath. The measurement and the issue of illegal monetary streams/capital flight is colossal thinking about the money related evaluation.

All around the evaluations demonstrate that unlawful streams/capital flight has developed generously and it is hard to measure given the wrongdoing of the streams and the basic exercises. Notwithstanding as indicated by moderate appraisals, about $€ 1,200$ billion crosses countries' outskirts unlawfully yearly. In 2008 , it was assessed that the entirety leaving the outskirts of creating nations is evaluated to comprise of over half of this, for example somewhere in the range of $€ 680$ and $€ 800$ billion. By method for examination, the improvement help paid by rich nations to creating nations was $€ 80$ billion same year 2008 , as is just 'a ninth or tenth part' of the riches that streams the other way illegally. The instances of Sub-Saharan Africa epitomize how genuine the condition looks. About €340 billion remaining the outskirts of this present world's most unfortunate area from 1970 to 2004. The remote obligation of the nations of the locale in 2004 added up to $€ 183$ billion. With intrigue the total expanded to $€ 490$ billion (Service Center for Development and Cooperation, 2010).

Besides, Global Financial Integrity (2017) gives evaluations of the unlawful streams/illegal budgetary streams (IFFs) out of the creating scene or illegal surges in 2014. It revealed that outpourings are evaluated to have run between $\$ 620$ billion and $\$ 970$ billion. Likewise Global Financial Integrity (2017) gauges that creating nations lose nearly US $\$$ one trillion every year. It has utilized exchange insights to evaluate that somewhere in the range of 2001 and 2010 African nations lost up to US $\$ 407$ billion from exchange mispricing as it were. In spite of the way that it is hard to gauge the definite figures being lost through IFFs/capital flight, accessible measurements by GFI and ECA demonstrate a rising pattern in the revolting advancement somewhere in the range of 2001 and 2013 even past.

Remote direct venture (FDI) has been the biggest single wellspring of outer fund for creating nations since 1993 however sadly, this is lost by means of capital flight/unlawful money related streams. Undoubtedly, in 1995, the portion of creating nations in worldwide Foreign Direct Investment (FDI) inflows arrived at a notable high of $38 \%$. Capital departure from creating nations is likewise more intricate than was recently suspected. For Latin America alone, occupants are evaluated to have lost about $\$ 300$ billion in capital abroad through capital flight/illegal outpourings.

Consequently the misfortunes acquired by African nations rise fundamentally despite the fact that a lot of outward unlawful monetary progressions of creating nations is about 4.6\% to $7.2 \%$ Global Financial Integrity (2017). Raymond Baker, who heads the International Task Force on International Integrity and Economic Development and the Global Financial Integrity research program, has expressed that capital flight is the absolute most destructive monetary issue for creating nations and transitional economies.

This immense illicit cross-fringe (IFFs/capital flight) challenge is dug in through duty safe house rehearses by MNCs, tax avoidance and evasion, defilement, sorted out wrongdoing, misrepresentation in global exchange through mis-invoicing, unlawful abuse of regular assets and redirection of open store from needs. Different structures through which unlawful outpourings happen incorporate illicit logging, angling and mineral extraction and these devastate people and networks that depend on these assets for their survival.

Ensuing upon unlawful money related streams (IFFs), there emerge political and financial security challenges far and wide particularly in creating nations. Neediness, financial impediment, poor way of life and general underdevelopment in all implications have turned into the standard in creating world. IFFs diminish residential assets and duty income expected to finance destitution decreasing projects and framework in creating nations. Developing countries have fallen victim of capital flight perpetrated by developed nations mostly through their agents, that is, multinational corporations. Though these multinational companies are welcome by their host developing countries with a view to speeding up development in all ramifications and increasing FDI, studies as stated above have shown that unknowingly to these developing countries, huge sum of capital/resources are illegally transferred to the countries of origin or parent companies of these MNCs abroad through their subsidiaries abroad in order to avoid/avert filling in their tax return to their host governments thereby robbing these developing nations of their resources through various tax havens practices and other illegal cross border practices. These developments render the citizenry and economy of developing nations poor as well as inhibit development. I lieu of these, it is the purpose of this study to investigate as a way of filling a gap, why foreign direct investments and valuable natural resources dwindle in developing countries where MNCs operate leading to constraints in poverty reduction programmes and developmental strides in these nations; despite the claims of MNCs that they attract developments.

1.1. Objective of the Study

To find the impact of capital flight on foreign direct investment in developing nations of Africa.

\subsection{Research Question}

Does capital flight have impact on foreign direct investment in developing nations of Africa? 


\author{
1.3. Hypothesis \\ Hypothesis1 ( $\left.\mathrm{HO}_{\mathrm{I}}\right)$ : Capital flight does not have dwindling impact on foreign direct investment in developing nations \\ of Africa.
}

\title{
2. Conceptual Framework
}

2.1. Illicit Financial Flows/Capital Flight Repatriation Explained

There is a developing level of recognition with the term 'unlawful money related streams', yet there is still no worldwide registration in regards to its definition. For example, the unlawful money related streams (IFFs) to relate both the progression of ill-conceived assets and resources crosswise over fringes and the center exercises that create the streams. It incorporates cash and exercises that have a clear connection with lawlessness, for example, defilement, illicit common assets misuse, sneaking and dealing, tax evasion, tax avoidance and extortion in global exchange. There is a continuous discussion on which business exercises speak to unlawful outpourings or capital flight. For instance, World Bank Group (WBG) is of the feeling that assessment evasion exercises, for example, lawful duty arranging and advancement don't have a place with IFFs/capital flight. This is unique from 'IFFs' that emerge through the false mis-valuing of products that occur between autonomous gatherings/backups, unlawful exchange evaluating inside worldwide organizations or imaginary exchanges.

Leonce Ndikumana, Director, Peri's African Policy Program, portrayed capital flight or illegal surges as the cash that leaves a nation which is unaccounted for or unrecorded. What's more, the greater part of the occasions it is cash that is spilling out of the nation in light of the fact that the proprietors are not willing to reveal the wellsprings of the assets, which may have been gained unlawfully. So it is fundamentally an overall deficit to the nation. It is assets that could have been put resources into the nation to advance venture, work creation, and monetary development. These assets are all of a sudden compelled to create wings to take off 12 PM or dissipate like gas, unnoticed.

Moreover, Service Center for Development and Cooperation (2010) clarified capital flight/illegal surges as unlawful riches that is earned, moved or utilized the repudiation of a nation's laws. It tends to be alluded to as riches whose starting point is associated with criminal behavior, for example, defilement, the unlawful assembling of products, other changing types of wrongdoing; it incorporates disguising an organization's riches from a nation's assessment specialists. The definition is utilized here of unlawful or illicit money related streams (or illicit capital flight) originates from the Global Financial Integrity contemplates, whose figures have been utilized by a wide range of advancement strategy associations, including the World Bank. By and by, most of unrecorded money related streams repudiate the laws of some nation, which is the reason it is sensible to discuss unlawful capital flight. The High-Level-Level Panel and GFI isolate IFFs into three classifications dependent on the wellspring of the stream and that is caught in an investigation by Service Center for Development and Cooperation (2010) as streams:

a. Debasement: This was the focal point of a wide-scope of talk during the 1990s, which records just for 3$5 \%$ of all these cash/illegal surges.

b. Universal crime: This incorporates medication and human dealing, tax evasion and so on which records for about $30 \%$.

c. Illicit business capital flight by means of tax avoidance by worldwide organizations is obviously of most noteworthy hugeness. This records for about $64 \%$ of capital flight repatriation/unlawful outpourings.

For this situation, reserves are moved from an organization to auxiliaries sited in various expense safe houses at exceedingly high or low costs. By interests in expense safe house organizations, the financial specialists can disguise their actual personality. For instance, enabling them to appreciate the advantage from uncommon treatment focused to abroad financial specialists. A comparable procedure can be utilized for laundering cash. For instance, on account of China it is evaluated that as much as a fourth of capital illicitly removed from the nation returns as remote ventures. China is popular as a nation of beginning of colossal unlawful money related streams. It is evaluated that up to $€ 80$ billion of assessable pay dissipates from China every year. Some worldwide organizations taking part in illicit capital flight are arranged and work together in rising economies. Tragically, around $80-90 \%$ of illicitly taken capital leaves creating nations for all time through these MNCs that guarantee they draw being developed.

When remote speculators utilize seaward organizations, shell organizations, and duty safe houses, they debilitate revelation measures and undermine the endeavours of reformers in Africa to advance straightforwardness. Such rehearses likewise encourage tax avoidance and, in certain nations, debasement, depleting Africa of incomes that ought to been sent to battle destitution and defencelessness'. Without a doubt, MNCs are childish in their business dealings in creating, investigating these improvements.

\subsection{Expense Haven Explained Inside the Extent of the Examination}

It has been seen that there is no sole meaning of a duty sanctuary. Duty sanctuaries have the accompanying highlights as pursues: 'low or non-existent tax collection, reluctance to take an interest in global trade of data on expense matters, organizations enrolled in them don't have to give real data on business movement in their very own region, and lacking straightforwardness'. 
Associations, for example, the OECD, the IMF and the Tax Justice Network meanings of expense asylums are somewhat extraordinary. This is the reason evaluations of the quantities of assessment safe houses shift. In 2008 the IMF assessed that there were 46 expense safe houses on the planet, while the Tax Justice Network included around 70 of every 2007.

\subsection{Western Tax Havens Sharp Practices Rob Developing Countries}

There are various natural expense safe houses, presumably little tropical islands like Bermuda or the Cayman Islands. Likewise, there are various expense shelters in Europe and the United States, whose states have wide rights to take choice freely on their tax collection and guideline of budgetary markets. Clearly little island states are constantly referenced as assessment shelters. This is on the grounds that their exceptional enactment makes it conceivable to get a low assessment rate for speculations and to disguise the genuine character of the financial specialists.

The EU, Ireland and Cyprus bait organizations with low expense rates and extraordinary laws. Belgium, Denmark, Luxembourg, the Netherlands and Switzerland charge some business exercises uncommonly gently and offer preferable open doors over tropical islands to repatriate their benefits untaxed to different nations. It is evaluated that the expense sanctuary benefits that goes on in the Netherlands alone on yearly premise speak to over $€ 100$ million shortage in the assessment income of creating nations. It is seen that an expected $5 \%$ of the abundance of private people put resources into expense sanctuaries has been exhausted as per the law in the nation of inception. The issue concerns poor nations just as rich ones: a few Indians have taken care of about $€ 1,100$ billion in Swiss ledgers, more than the residents of some other nation (Service Center for Development and Cooperation, 2010). This surge of assets wrongfully from such a creating world is over the top as it debilitates the income base the economy.

Assessment haven methods employed by Multinational Corporations (MNCs)

A portion of these strategies are quickly clarified underneath:

\subsection{Exemption/Deferral of Foreign Affiliate Income}

Most progressive countries commonly charge global home-nation tasks, yet don't furthermore, charge benefits of the organization's outside partners. Take for example, the US, treat the multinationals' overall pay (US just as outside) as assessable. Be that as it may, the US offers a gigantic hole. For instance, in the wake of making good on every nation's government obligations, the extra US charge on US multinationals' outside partner benefits can be conceded for an inconclusive period, possibly always, by the basic proportion of not moving those benefits back to the US. Rather, reserves are stopped in expense sanctuary, for example, Bermuda, or are put resources into other outside tasks where duty safe house exercises are possible. It is believed that if gathered, but not yet repatriated, the benefits of American multinationals' remote backups which have legitimately gotten away US tax assessment are evaluated somewhere in the range of \$2.1 and \$3 trillion. In this way, created nations are not excluded from expense safe house practices of MNCs however creating countries are most noticeably terrible hit on the grounds that to an enormous degree they rely upon incomes from their common assets being drained by MNCs.

\subsection{Transfer Pricing (Invoice Values)}

All inclusive as respects supply chains, multinationals deliver merchandise and ventures whose unit value, picked by the MNCs themselves, is often uncalled for by duty contemplations. A circumstance/situation where two firms, Firm X and Firm Y, both are possessed by the equivalent MNC. Firm X has been sending out 1,000 things for each year to firm Y invoiced at $\$ 1.30$ each. Yet, in the event that they are invoiced at $\$ 1.80$ every, Y would then pay X $\$ 500$ all the more yearly. Firm X's benefit would increment and Y's would diminish. The arrangement is straightforward; pay higher adds up to subsidiaries where expenses are low, and show lower esteems where duties as well as levies are higher. In the above model, if Y's nation's expense rates were higher than Firm's X, or in the event that X's nation imposed an import duty, at that point the circumstance would be switched. All things considered, the MNC included would underestimate the shipment to cut down its all-out overall assessment and duty risk.

This is where by a MNC move its corporate base camp to a lower-charge purview. This accomplished by basically securing or converging with a remote firm in a lower-charge nation. For huge worldwide organizations, the yearly reserve funds can be in billions. For instance, in Ireland, corporate expenses pegged at $12.5 \%$ contrasted and the greatest $35 \%$ US assessment rate. Since 2012 MNCs, for example, Mylan has moved to the Netherlands, Berger King moved to Canada, and Medtronic migrated to Ireland and in view of lower duty rates than the US.

\subsection{Different Uses of Tax Haven: Rounding-Tripping' and Evading Currency Convertibility Restriction}

MNCs set up shell or backup organizations which are utilized as a channel or parking space for outside associates' benefits that are not repatriated back to their nations of inception/home-nation however are utilized for outer ventures. Creating countries are hit by this advancement. By keeping benefits outside the nation of starting point, charge obligation on the income is conceded for an inconclusive period. In this way, benefits created by MNCs backups are not repatriated to their nations of origin to abstain from being saddled. 


\subsection{Intra-Corporate Loans}

One more arrangement government offer organizations is deducting interest instalments on credits as a cost thing. To be sure, instalments on credits are a cost of the borrower/payer. In any case, if the moneylender (wellspring of reserve) and the borrower are organizations inside the equivalent $\mathrm{MNC}$, despite the fact that in different countries, at that point the MNC has a make way to settling less government obligation in highcharge wards. It can make its lower-burdened members make advances accessible to its associates in highcharge countries and would then be able to appreciate a juicer charge reasoning on the intrigue instalment. FDI streams comprise of three segments:

FDI Flow $=$ New equity + Retained earnings + Net Intra-corporate advances.

Impact of capital flight and tax haven on the economy of developing countries.

There are various ways capital flight can influence the economies of creating countries and such include:

a. The exchange of riches from the poor South to the rich North additionally takes steps to negate the advantages got from advancement help and obligation alleviation from created countries. As it were, the advantages that could have been gotten from financials helps from global organizations and created countries are subtly detracted from the creating economies through capital flight repatriation along these lines leaving creating countries pretty much vacant.

b. Expense income of creating nations that could have financed speculations and spread open use is diminished.

c. Swelling and expanded pay differentials are prompted.

d. Interruption of rivalry and contracting of outside exchange.

e. Capital flight makes further dependence on benefactors also exacerbates the issue of obligation of creating nations.

f. Global partnerships by means of organization tax avoidance just power creating nations to lose charges that are impressively more prominent than improvement help they get from MNCs.

g. Trouble in fixing a market value: Transfer evaluating isn't unlawful as long as the backups are exchanging at "a safe distance", utilizing costs they would utilize on the off chance that they would be independent organizations. Ordinarily, the two purchasers and dealers go for the best cost from their own vantage positions. On account of exchange between the auxiliaries of MNCs, this standard does not generally hold. The cost might be set to a level that advantages most the parent organizations. This is the reason members split the benefits of their business much of the time in a manner that limits the organization's taxation rate. It ought to be noticed that move evaluating ends up unlawful when the various units of a MNC offer merchandise or administrations to each other at falsely or controlled high or low costs.

\subsection{Tax Avoidance Versus Charge Shirking}

Tax avoidance suggests the techniques by private people and organizations to maintain a strategic distance from tax assessment utilizing unlawful methods. This should be possible by giving deliberately incorrect expense data or covering it into. An organization may, for example, leave some portion of its salary undeclared or document an assessment form that has all the earmarks of being legitimate yet which as a general rule contains false data.

Duty shirking means exploiting lawfully of the escape clauses in the expense framework so as to limit charges. Forceful duty evasion involves enthusiastic abuse of provisos in expense laws and utilizing apparatus to move riches between various assessment frameworks to diminish in general tax collection. In spite of the fact that this isn't in contradiction of the law, it is additionally not in similarity with the standards of expense guidelines. An organization that will not pay the appropriate measure of duty in the ideal spot and at the correct time is acting against the soul of expense laws. Creating nation enactment and authoritative courses of action are generally less created and less powerful than those of created nations subsequently MNCs exploit such holes.

\subsection{Global Organizations as the Primary Wellspring of Capital Flight}

Assessment evading by MNCs represents $66 \%$ of the unlawful capital flight. MNCs can participate in different sorts of legitimate and illicit assessment arranging, especially by utilizing backup organizations situated in various pieces of the world - regularly duty safe houses. The system of auxiliaries gives likewise conceivable outcomes to exploit two-sided tax collection understandings. The most outstanding methods for tax avoidance is basically to give false data on the substance or make up of an organization's global exchanging. Auxiliaries situated in nations with low tax assessment can be made to show up most beneficial and the backups of nations with high tax collection most unfruitful so that there is no assessable salary made.

The costs utilized in exchange between the backups possessed by a parent organization are curved or injurious utilization of exchange costs between auxiliaries. Organization tax avoidance alone causes creating nations charge misfortunes that are obviously more prominent than advancement help from improvement accomplices and universal money related establishments. 


\subsection{Move Mispricing/Transfer Pricing}

The greatest segment of unlawful capital flight and corporate tax avoidance, results from deception of the substance and costs utilized in world exchange. The key strategy for this is controlling the exchange between organization's backups. This is called abuse of exchange evaluating, or move mispricing.

Move evaluating alludes to the costs that a worldwide enterprise utilizes in exchanging between its backups. In view of estimations, about $60 \%$ of global exchange happens among subsidiaries inside worldwide companies. Crude materials must be offered to their assembling plants and budgetary administrations from financing units to nation workplaces, etc. Move estimating can be abused by under-evaluating or overpricing items. Move mispricing is by a wide margin the most critical type of unlawful capital flight. As far as underevaluating of fares a MNC fixes the costs it utilizes in exchanging between its auxiliaries less expensive than the genuine estimation of the item. The items are then sold at current market cost in the nation of goal which as a rule far higher and the suggestion is higher benefits in the low charge locale. For this situation, the part of capital flight is basically the between the first and second cost. A similar system works the other route round: expenses can be maintained a strategic distance from by the overpricing of imports subsequently increment the expense of creation with its orderly decrease impact on benefits. The overabundance is then put resources into financial balances in nations with high level of banking mystery. The estimation of import and fare items can be controlled to be falsely high or low likewise by giving distorted data on their quality, order or amount. MNCs may likewise utilize imaginary exchange exchanges, which are paid for regardless of the way that the items don't exist. The instalment may then be moved from a country with heavier tax assessment to a zone with lighter tax collection.

\subsection{Backup Companies are the Main Tool of Tax Planning}

It has been seen that worldwide companies typically have several backups. Attributable to charge and different guidelines, backups are basically constantly settled in every one of the states where the parent organization has business tasks and most occasions in duty safe houses in which there is no legitimate business movement. A wide base of system of auxiliary organizations encourages the exchange of benefits to nations with the least conceivable degree of tax collection. Organizations in assessment sanctuaries are regularly holding organizations, whose solitary undertaking is to claim a parent organization's different backups and guarantee the accumulation of profits from them. These types of organizations are regularly settled in spots, for example, the Netherlands, Ireland, Luxembourg, Switzerland and Denmark-heaven of duty safe houses.

\subsection{How Capital Flight/Illicit Financial can be halted}

2.1 1.1. Guaranteeing Nation by-Nation Detailing would Handle Numerous Issues

Expanded straightforwardness in bookkeeping frameworks would be critical to control unlawful capital flight. It would likewise diminish the dangers related with business exercises. Current bookkeeping benchmarks are drawn up by a body containing experts from the private bookkeeping division, the International Accounting Standards Board (IASB) as of now known as International Accounting Standards Council (IASC). The IASB distributed its models without precedent for 2003. After two years they came into power in the European Union. As per faultfinders, the IASB standards are deficient. In the midst of lacking standards, organizations can report the wages of the backups of various nations as worldwide or provincial pay, so that scarcely anything is uncovered of an association's inside exchanging. As seen by Action Aid (2009) due to deficient straightforwardness, nation's residents, NGOs that screen government exercises or even individuals from parliament can't discover what sorts of understandings their pioneers have finished up with organizations.

Guaranteeing Greater Banking Transparency: The time of banking mystery is finished," the G20 nations announced in their announcement at the London Summit in April 2009. Authorizations should be forced on nations that work on banking mystery and to exchanges to banking mystery wards. The most noticeable activity so far has been the formation of dark and dim arrangements of duty safe houses drawn up by the OECD, however they are insufficient to tackle the issue. Their focal points remain especially irrelevant for most unfortunate nations. The budgetary emergency and goals of the G20 nation gathering have urged OECD to grow new activities against expense safe houses. The advantages for the creating nations from these activities stay restricted up until this point. There are a few serviceable arrangements in April 2009, the pioneers of the G20 vowed at their London Summit to construct "a more grounded, all the more all inclusive steady, supervisory and administrative structure" for the money related markets of things to come. As indicated by the Summit explanation, the world is set out toward "more noteworthy consistency and collaboration between nations". After the April Summit the OECD drew up supposed dark and dim records for uncooperative expense safe houses. Comparative records were first distributed as of now at the turn of the thousand years.

2.12. Endorses Instead of Voluntary Standards

2.12.1. The OECD has Likewise Sought after Assents against Nations Working on Banking Mystery

Data trade could be led likewise on a multilateral premise, with single worldwide understanding that all nations could sign. The framework could be developed to be programmed, so data would be accessible at 
whatever point required without a convoluted authorisation strategy. The EU as of now has a programmed data trade between experts on banking stores. Many duty safe houses outside the EU are likewise incorporated into the framework. The OECD also has some time ago sought after progressively complete, restricting models. As of now in 1988, the OECD drafted an agreement on programmed, multilateral data trade, yet just a couple of nations joined the understanding. Simultaneously the association began a program intended to check unsafe tax assessment rehearses, which tried to build reasonable challenge, transparency and data trade. Christian Aid (2008) noticed that the OECD report proposed sanctions, for example, prevention charges, against uncooperative duty safe houses. These sorts of activities would have been a progressive advance towards breaking the way of life of banking mystery.

\subsection{Giving more Power to the UN Tax Committee}

The United Nations is the main genuinely agent gathering for choosing worldwide principles and guidelines. The current UN Committee on tax collection (the Committee of Experts on International Cooperation in Tax Matters) ought to be refreshed to an intergovernmental organ. Rich nations have so far not been agreeable to a developing job for the UN in expense issues. A focal body for managing capital flight is the UN Committee on Taxation, set up in 1968. The master advisory group examines charge understandings, charge evading, tax avoidance and capital flight, advances universal collaboration on tax assessment and supports the duty experts of creating nations. Toward the part of the bargain, charge council started to manage UN procedural guidelines went for nearer participation in global assessment evading. The procedural guidelines characterized least gauges for the two nations and private on-screen characters, which must be connected to handle capital flight, charge shirking and tax avoidance.

\subsection{Earnestness of Powerful Financial Institutions, for Example, the IMF and the World Bank}

Increasingly dynamic participation and data trade between states alone isn't sufficient to take care of the issue of capital flight. The ground-breaking universal money related organizations, the World Bank and the IMF, should pay attention to the issue. The universal financial store (IMF) coordinates the monetary and tax assessment arrangements of poor and obligated nations from numerous points of view. The IMF still urges creating nations to shun controls on the development of capital. For example, it trains poor nations to deregulate their capital and further destroy guidelines on the money related markets. Deregulating the capital records prompts lost oversight over seaward exchanges and the outside speculations coordinated at the nation. Disassembling the guideline of the monetary markets reduces the potential outcomes for states to screen universal money related streams and to impact them. The money related emergency has mainstreamed that self-guideline of the business sectors is lacking for forestalling business sector stuns and guaranteeing appropriate oversight. This perception has not, notwithstanding, provoked the budgetary organizations to change their standards on a very basic level. It can be further ascertained that creating nations have additionally been encouraged to dispense with import obligations and to supplant the lost income with buyer charges, which especially influences the least fortunate of the populace.

\subsection{Outside Direct Investment Explained}

The globally acknowledged meaning of FDI is caught in the fifth release of the IMF's Balance of Payments Manual (1993). Remote direct venture (FDI) is speculation made to obtain an enduring enthusiasm for or successful power over an endeavours working outside of the economy of the financial specialist. Concerning this definition, FDI has three parts: value speculation, reinvested income, and present moment and long haul between organization advances between guardians firms and remote associates. These components of direct speculation capital exchanges are recorded on a directional premise (for example inhabitant direct speculation abroad and non-occupant direct interest in the account economy). The FDI net inflow records the net progression of non-inhabitant direct interest in the chronicle economy, while the FDI net outpouring records the net progression of occupant direct venture abroad. FDI net inflows are the estimation of internal direct speculation made by non-inhabitant financial specialists in the revealing economy, including intraorganization credits, net of repatriation of capital and reimbursement of advances.

Thus, FDI net surges are the estimation of outward direct venture made by the occupant of the detailing economy to outside economies including re-contributed profit and intra-organization credits, net of receipts from the repatriation of capital and reimbursement of advances.

As recognized from different types of worldwide speculation, FDI is made to make an enduring enthusiasm for or powerful and productive administration authority over a firm in another nation.

\subsection{Theoretical Framework}

There are disparate perspectives on how capital flight/capital portability/unlawful money surges influence financial and social parts of society or any country particularly creating country. The hypothetical outline or foundation is talked about hereunder.

There are five perspectives on the conceivable impact of MNCs and FDI on the heading the world economy is going. These are named 'the Race to the Bottom', 'the Climb to the Top', 'Neo-liberal Convergence', 'Uneven Development', and 'A lot of excitement about something that is not important'. The 
examination settled with 'the Race to the Bottom' see. As per this view, capital will increasingly more have the option to repay labourers, networks and countries off against each other, while it will take steps to flee once there is interest for expense, administrative and wage concessions are not approaching. In this point of view, expanded capital versatility benefits companies, while labourers and networks lose. A changed form of this view is that the victors in the race to the base will incorporate profoundly taught and talented specialists, and those in favoured callings, regardless of where they live. The failures will be the less gifted and the jobless all over the place. With the end goal of this investigation we receive 'the race to the base' see since it has association with the reason MNCs and outside speculators enjoy unlawful capital repatriation prompting colossal misfortunes by their host networks and nations furthering their own potential benefit.

\subsection{Review of Empirical Studies}

In an investigation by Rabah et al. (2014) on the connection between common assets and capital trip as assessment evasion from worldwide enterprises, it noted overflow impacts as far as duty income preparation and financial exchange improvement from the slight capitalization rule, a strategy instrument planned for restricting firm charge shirking through setting limits on a company's remote obligation. The investigation misused the conceivably exogenous inside nation varieties of information on oil disclosures for a gathering of nations during the period 1970-2012. It was found that oil revelations altogether help both assessment income assembly and financial exchange advancement, yet just when dainty capitalizations standard is set up. The examination along these lines presumed that through, capital flight executed by MNCs, tax avoidance is settled in creating countries subsequently the loss of capital in such nations and this achieves disintegration of residential duty base.

Administration Center for Development and Cooperation (2010) in an investigation on the connection between remote speculations and active benefits in some African nations 1995-2003, with information from IMF and World Bank and so forth, applying straightforward rate in calculation and correlations noticed that benefits repatriated by MNCs far exceed their interests in creating countries as demonstrated in Table 1.

Table-1. FDI, Capital flight and the identified variance from 1995-2003.

\begin{tabular}{c|c|c|c}
\hline Country & $\begin{array}{c}\text { Foreign-direct investment } \\
\text { by MNCs(1995-2003) } \\
(€ \text { Million) }\end{array}$ & $\begin{array}{c}\text { Capital flight caused by } \\
\text { MNCS (1995-2003) } \\
\text { (€ Million) }\end{array}$ & $\begin{array}{c}\text { Difference } \\
(€ \\
\text { Million) }\end{array}$ \\
\hline Botswana & 835 & 4,980 & 4,145 \\
\hline Gabon & 725 & 3,040 & 2,315 \\
\hline Nigeria & 9,545 & 10,965 & 1,420 \\
\hline $\begin{array}{c}\text { Democratic Republic of } \\
\text { Congo }\end{array}$ & 1,435 & 2,455 & 1,020 \\
\hline Mali & 715 & 725 & 10 \\
\hline Gross total & 13,255 & 22,165 & 8,900 \\
\hline
\end{tabular}

Source: Authors calculations, 2019.

Worldwide monetary integrity in an investigation/report to decide the pace of capital trip in creating nations, found that capital trip with the aim to avoid assessment forms are of different structures such illicit business capital trip by MNCs adding up to $64 \%$, global wrongdoing evaluated at $30 \%$ and defilement between 3-5\% (World Bank, 2015). The examination further saw that in China it is assessed that as much as a fourth of capital wrongfully removed from the nation returns as outside speculations. China is the most significant nation of root of unlawful monetary streams: About $€ 80$ billion of assessable salary vanishes every year. Some global organizations taking part in unlawful capital flight are domiciled and working in rising economies, yet by and by, around 80-90 percent of illicitly taken capital leaves creating nations for all time. As a method for filling a hole distinguished in the past investigations, this examination chose to consider the effect capital of flight repatriation on FDI from 2005-2014 in the accompanying chosen nations in Africa-Botswana, Cameroon Gabon, Nigeria and South Africa. The information acquired from UNCTAD and IMF/World Bank databases were broke down with least square relapse with E-View 92017 Software to decide the degree of the effect of capital flight repatriation on FDI .

\section{Research Methodology}

The exploration configuration is Ex-post facto. The examination utilized auxiliary information. Auxiliary information were gotten from the databases of Global Financial Integrity and UNCTAD, FDI/MNE database including distributed examined works by Global Financial Integrity, IMF, World Bank, Kar, Dev. what's more, Kar and Devon (2009).Others incorporate OECD reports, course books and different materials in presence embraced in clarifying the looked into factors. The examination acquired information on Foreign Direct Investment (FDI) and Illicit Capital Flight from 2005 to 2014. Population: Countries in Africa.

Sample size: Five countries from different African sub-regions namely Botswana, Cameroon, Gabon, Nigeria and South Africa. The results of the data analysis and hypothesis testing with ordinary least square 
regression using E-views 9 Computation, 2017 presented reliable evidence upon which this study draws conclusions.

3.1 Model Specification

The model for this study is expressed in the equation below:

$$
\mathrm{FDI}=\mathrm{f}(\mathrm{CF})
$$

Where:

FDI = Foreign direct investment.

$\mathrm{CF}=$ Capital flight.

For estimation purposes, equation (1) is re-written as follows:

$$
\mathrm{FDI}=\beta_{\mathrm{o}}+\beta_{1} \mathrm{CF}+\mu
$$

\section{Where:}

$\beta_{\mathrm{o}}=$ Constant parameter .

$\beta_{1}=$ Estimation parameter

$\mu=$ Error term.

Below is the descriptive statistics and chart representation of the data collected. The essence was to give a cursory review of the statistical properties and trend of the variables employed.

\subsection{Presentation and Analyses of the Results of Data}

The analysis of the secondary data with ordinar least square regression gives more attention to the null hypothesis and the interpretations give a reasonable validity and reliability on the findings, conclusions and recommendations of the study. The results of the hypothesis shows that Capital flight repatriation has significant effect on foreign direct investment which represent t-statistic of 2.531 with $\mathrm{F}$ - statistic $=21.70 ; \mathrm{R}^{2}$ $=0.837$, and $\mathrm{R}^{-2}=0.701$ with the p-value $0.016<0.05 \%$. Based on the outcome of the hypothesis testing, this study draws conclusions.

The Table 2 is a representation Researchers' of FDI and Capital Flight from the databases of UNCTAD, FDI/MNE database (www.unctad.org/fdistatistics)/Global Financial Integrity Report, 2017 2005-2014.

\begin{tabular}{|c|c|c|c|}
\hline Country & $\begin{array}{l}\text { Foreign direct investment } \\
(\$ \text { Million })(2005-2014)\end{array}$ & $\begin{array}{c}\text { Illicit capital/capital } \\
\text { outflows (\$ Million) (2005- } \\
2014)\end{array}$ & $\begin{array}{c}\text { Difference } \\
(\$ \text { Million) (2005- } \\
\text { 2014) } \\
\end{array}$ \\
\hline Botswana & 4,701 & 8,794 & 4385.5 \\
\hline Gabon & 5397.2 & 10,976 & $5,578.8$ \\
\hline Nigeria & $60,326.2$ & 173,158 & $112,831.8$ \\
\hline Cameroon & 3239.3 & 3,828 & 588.7 \\
\hline South Africa & $50,068.8$ & 83,898 & $33,829.2$ \\
\hline Gross total & 123732.5 & 280654 & 157214 \\
\hline
\end{tabular}

Table-2. Global financial integrity report, 2017.

Source: UNCTAD, FDI/MNE database (www.unctad.org/fdistatistics)/Global Financial Integrity Report, 2017.

Bar chart representation of the Table 2:

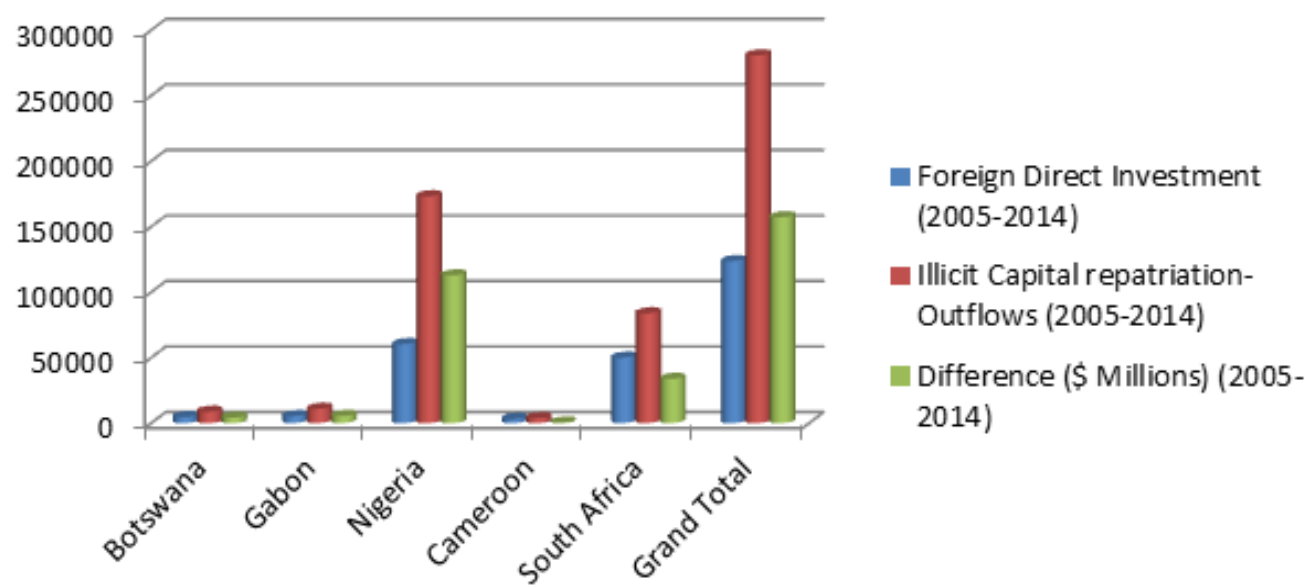

Figure-1. Global integrity report, 2017

Source: Researcher's multiple Bar Chart Presentation of FDI and Capital Flight from the databases of UNCTAD, FDI/MNE database (www.unctad.org/fdistatistics)/Global Financial Integrity Report, 2017 2005-2014. 
Table-3.Capital flight and foreign direct investment.

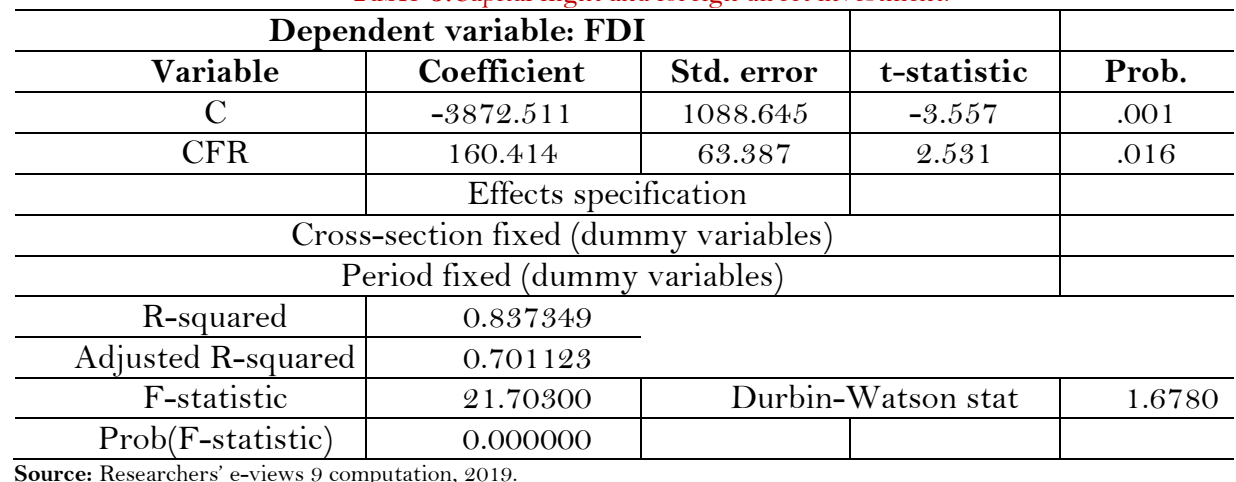

The result in Table 3 shows that Capital flight has significant effect on foreign direct investment which represent $\mathrm{t}$-statistic of 2.531 with $\mathrm{F}$ - statistic $=21.70 ; \mathrm{R}^{2}=0.837$, and $\mathrm{R}^{-2}=0.701$ with the p-value $0.016<$ $0.05 \%$. Furthermore, it can be deduced from the result obtained that the constant parameter in the long run is positive. This implies that if all the explanatory variables are held constant (in this case does not increase), foreign direct investment (FDI) will increase. However, if these illicit revenues are invested wisely, by foreign investors in the these developing nations where their businesses are domiciled, it will generate employment, increase Gross Domestic Product (GDP) of these nations, decrease interest rates, impact positively on exchange rates as well as help in nation building in less developed nations. Therefore, the study concluded that capital flight to a large extent has a significant impact on foreign direct investment in developing nations.

\subsection{Result and Discussion}

The result in Table 3 E-view 9 computation, shows that Capital flight has significant on foreign direct investment which represent t-statistic of 2.531 with $\mathrm{F}$ - statistic $=21.70 ; \mathrm{R}^{2}=0.837$, and $\mathrm{R}^{-2}=0.701$ with the p-value $0.016<0.05 \%$. That is to say that in the long run when the explanatory variables are held constant, foreign direct investment (FDI) will increase and the constant parameter in the long run will be positive. However, if these funds are invested wisely, by foreign investors in the these developing nations where there businesses are domiciled, it will generate employment, increase Gross Domestic Product (GDP) of these nations, decrease interest rates, impact positively on exchange rates as well as help in nation building less developed nations. Therefore, the study concluded that capital flight repatriation to a large extent has a significant impact on foreign direct investment in developing nations. This is in line with a study by Service Centre for Development Cooperation (2010) with data generated from IMF database. The study revealed that profits repatriated by MNCs from developing countries between 1995 and 2003 was much greater than foreign direct investments (FDI) by MNCs within the period given. Within the period 1995-2003, profits repatriated which constitute capital flight from the following countries are as follows: Botswana $€ 4980$ million, Gabon $€ 3040$ million, Nigeria $€ 10965$, Democratic Republic of Congo €2455 and Mali $€ 725$ million bringing the total amount that left these developing nations via illegally equal to $€ 22,165$. This shows a massive capital flight caused by MNCs with the aim of evading and avoiding tax payment and intentionally looting the resources of these helpless nations thereby robbing them of the gains (profits) that should have been accrued to them via FDI. Rabah et al. (2014) using plausibly exogenous within the country variations of data on oil discoveries for a panel of 117 countries during the period 1970-2102, concluded that through capital flight perpetrated by MNCs, tax evasion is entrenched in developing nations hence the loss of capital in such countries and this brings about erosion of domestic tax base.

\section{Findings and Conclusion}

The objective of the study in specific terms is to unravel the fact that through the selfish illegal activities of MNCs such as tax evasion and avoidance, corruption and various forms of crimes such as money laundering, developing countries are robbed of gains (profits) accruing from foreign direct investment (FDI) and the consequences include retarded development resulting in low standard of living, poor infrastructure, unemployment et cetera. The study has revealed that MNCs indulge in various tax haven related activities in developing countries, a major one being illicit capital flight through mis-invoicing, fictitious and transfer pricing through their subsidiaries. Besides, these poor nations are left at the mercy of MNCs that have the technology to develop their resources hence they negotiate low tax rate with the governments of these nations to their selfish interest alone. The study goes further to establish that MNCs loot the resources of developing nations by repatriating in excess of what has been invested by developed nations and even financial aids from international financial institutions. In addition, impoverishment of the citizens of developing nations and their economies are occasioned when the national resources of these less developed nations that should have been used to develop them are tapped by MNCs and the proceeds therein disappear via their illegal economic acts. 


\section{Policy Implication and Recommendations}

The policy implication is that the developing nations' government may not have enough revenue to initiate proper development if the capital flight remains a practice among the Multinational Corporation. The low tax rate MNCs agree with the government is not commensurate with the level of environmental damage their activities cause the emerging nations. Thus, policymakers ought to require worldwide organizations to openly uncover their incomes, benefits, misfortunes, deals, charges paid, auxiliaries, and staff levels on a nation by-nation premise.

Governments ought to set up open libraries of confirmed gainful proprietorship data on every single legitimate element, and all banks should know the genuine valuable owner(s) of any record in their money related organization.

Government experts ought to receive and completely execute the majority of the Financial Action Task Force's (FATF) hostile to illegal tax avoidance suggestions; laws as of now set up ought to be unequivocally upheld.

All nations ought to effectively take an interest in the overall development towards the programmed trade of expense data as embraced by the OECD and the G20.

As for exchange mis-invoicing, traditions offices should treat exchange exchanges including an assessment safe house with the most abnormal amount of examination.

Governments ought to altogether support their traditions implementation by preparing and preparing officials to all the more likely distinguish deliberate mis-invoicing of exchange exchanges, especially through access to constant world market evaluating data at a nitty gritty item level.

An exclusive hazard appraisal application (an item to help government in the location of potential misinvoicing continuous) known as GF Trade has been created to empower traditions authorities to decide whether merchandise are valued outside commonplace extents for similar items ought to be embraced by creating countries encountering monstrous capital flight.

The study therefore recommends that more stringent international tax laws aimed at entrenching transparency on how MNCs file in their tax returns should be enacted. In collaboration with OECD, IMF, World Bank Group and UN and other development partners, any MNCs, individuals, group of individual and institution found indulging in illicit capital flight by creating any form of tax haven or any form of illegal loopholes should be sanctioned severely. Developing nations ought to strive to develop their traditional technologies and embrace hi-tech in all sectors in order to be well positioned to harness these natural resources independent of MNCs.

\section{References}

Action Aid, (2009). Breaking the curse: How transparent taxation and fair taxes can turn Africa's mineral wealth into development. Available from: www.actionassistance.org/main.aspx?PageID=1319 [Accessed August 2009].

Christian Aid, (2008). Death and taxes: The true toll of tax dodging. Available from: www.christianassistance.org.uk/images/deathandtaxes.pdf. [Accessed August, 2009].

Global Reporting Initiative, (2006). GRI guidelines, economic indicator protocol, EC1, version 3.0, sivu 5. Available from: www.globalreporting.org/NR/ rdonlyres/A4C5FA04-3BD3-4A02-B0836B3BooDEAF61/o/G3_IP_Economic.pdf. [Accessed August 2009].

Global Reporting Initiative, (2017). GRI guidelines, economic indicator protocol, EC1, version 3.0, sivu 5.

Global Financial Integrity (2017), Illicit Financial Flows to and from Developing Countries, 2005-2014, Washington, DC: April. Available from: https://www.gfintegrity.org/wpcontent/uploads/2017/05/ GFI-IFF-Report-2017_final.pdf.

Kar, D. \& Devon, C. (2009). Illicit financial flows from developing countries 2002-2006. Global financial integrity. Available from: www.gfip.org/storage/gfip/documents/executive - final version 05-1409.pdf. [Accessed August 2009].

Service Centre for Development Cooperation, (2010). Illegal capital flight from developing countries. Series: 101.

Rabah, A., Gregoire, R.G. \& Lemma, W. S. (2014). African economic research. Consortium and University of Maryland (Senbet), CERDI-CNRS and FERDI (Rota-Graziosi).

World Bank, (2015). The world bank group's response to illicit financial flows: A stocktaking.

IMF, (1993). IMF's data on FDI on Balance of Payments Manual 1993. 